\title{
GLOCALITY AS INSTRUMENT OF CULTURAL POLICY AND ITS ABILITY TO PRESERVE CULTURAL CAPITAL
}

\author{
Kamo Chilingaryan, \& Ekaterina Zvereva \\ Foreign Languages dept. at Law Institute, RUDN University, Moscow (Russia)
}

\begin{abstract}
Glocality today is a universal form of reflection of contemporary reality and, as a category of social philosophy, dialectically connects the concepts of "global" and "local." The terms "glocality," "glocalization," and "glocal" have their definitions and are actively used to describe and analyze the corresponding phenomena occurring in the life of society. Some events in the life of modern society can be explained only with the help of the concept of "glocality."

In this work, the authors set the goal of analyzing the nature of the interaction between global and local and identifying the possibilities for their harmonious coexistence. The research methodology determined the purpose and focus of the work. The authors conducted a comprehensive analysis of examples, which are a synergy of global and local characteristics of the existence of human society. In the course of the work, various methods were used, the main of which was inductive empirical, which consists in observing, fixing, generalizing and interpreting facts that serve as the basis for general conclusions. The hypothetical-deductive method was used to present the results of the study when, in some cases, general observations were given before particular examples.

Property rights may collide with other rights. We must understand the complex process of glocalization through direct and critical research simultaneously - detailed research and fine-tuning of everyday cultural practices, symbolic imaginary, and social relationships that reproduce global processes, connecting various distant planetary points. This includes looking at how global markets interact with political rules, social forms, and the production of cultural property through disparate and heterogeneous stories and geographies.
\end{abstract}

Keywords: Globalization, glocalization, localization, culture, civilization.

\section{Introduction}

The modern world is the coexistence of different cultures with their values and pace of life. The term "coexistence" itself implies the close interaction of these cultures and people belonging to one or another culture. Moreover, this interaction is growing stronger over time and the development of science and technology: the infrastructure of cities is developing, the type of technology is changing, and as a result, the pace of people's lives is greatly influenced by the Internet, mass communication, mobile communications. The term "interaction" is gradually beginning to give way to such a term as "interpenetration," or perhaps even "mutual influence," which, of course, cannot but affect people's lives.

The phenomenon of globalization, on the one hand, and localization, on the other, has received the definition of glocality or glocalization. Moreover, the term "glocality" is acquiring a stable position of a scientific term.

"Global" and "local" are fundamental manifestations of reality. Globalization is an immanent "dialectic" process, defined by a series of empirically recorded changes, heterogeneous, but united by the logic of transforming the world into a single place.

Globalization of culture is considered to be the destruction of cultural identities under the influence of consumer culture. The global institutionalization of the world is interpreted as the organization of everyday local interactions and socialization by the direct influence of macrostructures of the world order. The second aspect - the localization of globalism - reflects the tendency to implement global through local. In this case, "global" is not only "international," but also "local" to the extent that the latter is globalized. 
Among the general public, as well as sociologists, there is a popular point of view that the globalization of culture is associated with the destruction of cultural identities under the influence of the consumer culture. For many of them, it is the Western culture and global capitalism that impose their cultural products on the entire world, in the meantime, standardizing and unifying society. A. Giddens (2000) is one of those who consider that globalization produces integration and disintegration, cooperation and conflict, order, and disorder. The cause and reasons for such a belief may be adversarial.

Globalization is a process of global economic, political, and cultural integration and unification. In his work "Socjologia Analiza Społeczeństwa," P. Sztompka (2002) mentions that the birth of the word "globalization" is associated with the name of the English scientist R. Robertson (1992), who in 1983 used the term globality in the title of the article "Discussing Globality," and in 1992 outlined the basics of his concept (the idea of the integrity of the world due to the spread of achievements of Western civilization).

How does globalization affect the culture? Robertson proposes to replace the central concept of cultural globalization with the concept of "glocalization" - a combination of the words "globalization" and "localization." "Globalization - at first glance, something enormous, external that is approaching and ultimately suppresses everything else - is perceived in specific small manifestations, in local life, on one's own life, in the symbols of a culture marked with the sign "glocal" (1992).

\section{Literature review theoretical background}

Discussions and debates about the development of human civilization, the place of national cultures in it and their relationships have been going on for centuries: J. Habermas (1992: 8) stated the "new irreversibility," Z. Bauman (2000: 8) speaks of "the end of uniqueness." Local and global, as Robertson (1992: 91) claims, do not exclude each other.

On the contrary, the local must be considered as an aspect of the global. "Globalization, among other things, also means the contraction, the clash of local cultures, which should be given a new definition in this "clash of localities" [ibid]. Thus, the modern cultural space is a space of glocalization processes, and more precisely, it can be explicated as a glocal culture. Glocal culture is a world cultural space in which the interaction and interpenetration of local cultures as cultural and historical entities with their mentality and the ability to preserve their identity in the context of globalization are carried out.

According to P. Berger and S. Huntington (2004), the most critical "globalizers" are Americans. It is due to the increased US influence in the world in the second half of the 20th century. P. Sztompka believes that homogenization embraces the world, and above all, the core of culture - the language, because it is English that has become the global medium of communication, the language of business, and programming. In "Tyranny of the Moment," Thomas Hylland Eriksen (2001) talks about speeding up the time as one of the fundamental elements of globalization. The critical lack is control over one's own time. All that needs to be done quickly - threatens to supplant what needs to be done slowly.

The concept of glocalization allows us to understand the multiple relationships between global and local. The concept is modeled based on the Japanese concept of "dochakuka" (becoming a native), which, in turn, comes from "dochaku" (a native living in the homeland). Initially, this concept was related to the agricultural principle of adapting cultivation methods to local conditions. As S. Tulloch (1991: 134) mentions, in the 1980s, the Japanese businessmen adopted the term to refer to a global location or "global view adapted to local conditions" (1991). The concept soon spread throughout the world. Featherstone (1996: 64) presents an example: the American multinational Coca-Cola has put forward its version of glocalization under the slogan "we are not multinational, we are multilocal" (1996). Robertson (1994-95) argued his position as the need to resist the tendency to perceive globalization, as if it were only large-scale macro-sociological processes, neglecting the positioning of globalization. In other words, globalization always happens in a particular place, while local is (re)created in the discourses of globalization.

Robertson's point of view is similar to other models of cultural globalization that explore global-local intersections (Appadurai, Friedman, Hannerz, Pieterse). Chang, Milne, Fallon, and Pohlmann (1996), for example, argue that "global and local must be intertwined in any future theoretical framework designed to help understand the processes and results of the humanitarian heritage" (1996: 285). In the same way, Teo and Lee (2003) point out that "for culture, the concepts of global and local form a dyad that acts as a dialectical process" (2003: 302).

Studies of sociocultural aspects were based mainly on the "invited-guest paradigm," drawing attention to local influences (V. Smith). Aramberri (2001), Franklin and Crang (2001), and Sherlock (2001) agree that while maintaining a static and exclusive view of cultures and local characteristics, this model does not cover all the complex interactions between people and their glocalized environments. Most of the difficulties in interpreting glocalization are associated with the false opposition between 
globalization and localization. Nuryanti (1996), for example, indicates that studies on the cultural vector are often characterized by a series of contradictions between the strength of tradition (local), which implies stability or continuity, and innovation in various fields (global strength): this means or implies a change.

Interestingly, it is in the field of culture and artistic heritage that the global-local dynamics have been studied, and here Teo and $\mathrm{Li}$ should be mentioned (2003: 290). Whereas in its original micro-market, the meaning of glocalization refers to the production of global products adapted to specific circumstances, in the case of a cultural component.

Cultural globalization as glocalization is characterized by the convergence of business and consumer culture between different countries of the world and the growth of international communication. On the one hand, this leads to the popularization of certain types of national culture around the world. On the other hand, widespread international cultural phenomena can supplant national ones or turn them into international ones, often even acquiring their cultural coloring.

The globalization of culture is associated with two phenomena. The first is the spread of Western individualistic values among a growing part of the world's population. These values are promoted by social institutions that recognize individual human rights and attempts to protect human rights at the international level. The second trend can be called borrowing of Western "rules of the game" around the world. Bureaucratic organization and rationalism, materialistic views, values of economic efficiency, and political democracy have been spreading in the world since the time of the European Enlightenment. The influence of Western values: rationality, individualism, equality, efficiency is overgrowing. However, the opposition to them is growing every year.

\section{Where global turns to local?}

Before the era of globalization there were strong ties; identity was a collective possession of local communities. Today, globalization has contributed to the erosion of the sacred values: ethnocultural identities are disappearing, creating a homogeneous, pragmatic, and rationalized context devoid of the sacred dimension. According to American socio-cultural anthropologist A. Appadurai (1996), globalization is a deterritorialization, i.e., the loss of the attachment of social processes to physical space. He explores global cultural flows, consisting of cultural-symbolic spaces-streams (landscapes): ethnoscape is formed by a stream of tourists, immigrants, refugees, migrant workers; technology space (technoscape) - a stream of technology; Finanscape - a stream of capital; media space (mediascape) - a stream of news; and ideoscape - by a stream of ideologeme - a fundamental unit of ideology.

Globalization contributes to the structural complication and meaningful enrichment of identities, their hybridization, as a result of which the identity becomes multi-layered, combining ethnocultural and global levels in a single structure. Thus, globalization eventually propagates identities but does not destroy them. At the same time, cultural globalization is a complex and in-depth process. It is not just the cultural colonization of the world by some countries. It is an intense, though not always equivalent, cultural exchange between societies.

Modern researchers of the globalization phenomenon speak of a complex process of interweaving global trends in social development and local or customary features of cultural development, defining this phenomenon as the phenomenon of glocalization. In any culture, there is glocalization. The process of glocalization is as follows: in the framework of expanding contacts with the outside world and Western culture, the emphasis is shifting more and more to the "local" component than to the "global" one.

The phenomenon of glocalization and localization can be seen in several examples.

Americanization in the food industry in India is not widespread among Indian consumers. McDonald's has faced several problems, despite a pre-developed market penetration strategy that has been successfully tested in other countries. The idea of a hamburger does not take root in India even among the most Europeanized part of the population. The protest of the Indian population against the McDonald's fast-food restaurant was associated with the beef in a burger, which is unacceptable for most Indians. McDonald's had to adapt its menu to local conditions: the labels on the big mac were changed into maharaja mac, such local dishes as a vegetarian burger, panir-salsa (fried home-made cheese with vegetables and spices) and panir-tikka (a small rectangular cheesecake with cottage cheese and vegetables with spices) appeared; black tea and coffee are served, according to the Indian tradition, only with milk.

Cultural patterns are transferred from one country to another and are taken mainly through the media. The Internet plays a huge role in cultural globalization. As an example of glocalization, the cultural peculiarities of IT-companies can be considered. Search engines are glocalized. The diversity of humanity and its cultural forms can be observed on the Internet. "Google" is not the only search engine in absolutely all markets, as some people may think. 
Nevertheless, it is now striving to adapt to the cultural characteristics of different countries. P. Sztompka states that the core of culture is language, which is why we can observe vivid cultural features and local trends among search engines. In China, Baidu.com has a market share of $78 \%$; in Japan, it is Yahoo with $60 \%$, and in Russia - Yandex has $46 \%$, far ahead of Google.

In all the countries as mentioned earlier, the local search engines provide for an interactive knowledge-sharing platform, an encyclopedia, and a social network. Baidu.com also has vertical searches - maps, news, videos, pictures, and more. Yahoo is developing many new services, such as "Yahoo Messenger," "Yahoo Mail," "Yahoo Maps," "Yahoo Finance," "Yahoo Groups," "Yahoo! Mobile", "Yahoo Shopping," and others for mainly two markets: USA and Japan. Yandex.ru is now operating in some CIS countries and builds its work on the local needs, analyzing the market, both global and local.

\section{Discussion and conclusion}

Globalization is the reason for the revival of local cultural identity in many parts of the world. Giddens A. (2000) comes with a question: if globalization created a united world, no one would ask: why, for example, the Scots are striving for more independence within the United Kingdom, and in Quebec, there is a powerful separatist movement? The answer is simple; it is the local nationalism that is reviving in response to globalization trends.

Cultural globalization today is not just westernization. Globalization is associated not only with unification but also with the interpenetration of cultures and their constant interaction and mutual exchange. For example, the performance of multinational corporations depends on their flexibility and ability to adapt to the cultures of different countries. Global culture is accepted, but with significant local modifications, the process of glocalization is taking place.

In their work, "Many Globalizations: Cultural Diversity in the Contemporary World," Peter L. Berger and Samuel P. Huntington argue that along with glocalization and localization, there is such a thing as easternization or alternative globalization, i.e., global cultural movements that arise outside the West and have a strong influence on it (2004). Alternative globalization can be attributed to religious movements generated by India, Buddhist movements that came from Japan and have great success in the West.

The globalization of culture does not mean that groups and individuals become the same in the cultural framework; instead, new cultural differences and accentuations are emerging in the context of local-global interaction. Thus, global changes in culture are not connected with the loss of its national originality by the state, the imposition of specific standards on the whole world, and the total unification. It is in the period of global changes in all areas of society that a sense of national identity intensifies, and localization and glocalization processes take place.

Thus, the value-semantic foundations on which the modern philosophy of glocalization is based, establish new principles of the relationship between humans and nature, transform the mechanism of civilizational development that has been taking shape over the centuries. As Sztompka P. (2002) states, contribute to the formation of unique spatio-temporal structures in culture, changing both the cultural-historical types and their forms of interactions, sometimes without even taking into account that "the only basis for tolerant relationships between cultures can be the idea of equality of all cultures and peoples." Accordingly, the ideas about the future of humankind become different, and the question of the fate of cultures is directly related to the question of the fate of their bearers, because the dominant "eccentric" strategy does not contribute to the way out of modern civilization from the systemic-paradigmatic crisis, the manifestations of which are associated with the intensive growth of scientific and technological achievements in all spheres of human life.

Thinking of globalization and localization as opposing processes is not very useful for understanding and explaining contemporary global multiculturalism. The constant (re)formulation of the local in many respects is part of the globalization process and is also globalizing itself. The processes of glocalization are not limited only to culture. However, using the theoretical concept of glocalization is very instructive for understanding socio-cultural dynamics. This helps to understand that, for example, globalization is developing not so much as overcoming cultural differences, but through the permissiveness of such differences and their strengthening. At the same time, it is essential to note that the concept of glocalization represents only an analytical perspective and not a defining theory. For researchers, the study of culture is the task of elucidating the boundaries between global and local.

From an analysis of the daily practice of multicultural relationships and how to (re)represent and (re)actively create a local culture for a diverse global audience, one can learn a lot about how globalization and localization are intertwined and how this glocalization - through tourism and other channels - transforms culture. 
In general, we must understand the complex process of glocalization through direct and critical research simultaneously - detailed research and fine-tuning of everyday cultural practices, symbolic imaginary, and social relationships that reproduce global processes, connecting various distant planetary points. This includes looking at how global markets interact with political rules, social forms, and the production of cultural property through disparate and heterogeneous stories and geographies. More research is needed to understand how certain aspects of everyday life are glocalized, and how this process of glocalization - which is significantly differentiated according to geographical and political coordinates - deeply affects culture and the contemporary humanitarian environment.

\section{Acknowledgements}

The publication has been prepared with the financial support of the «RUDN University Program 5-100».

\section{References}

Appadurai A. (1996) Modernity at large: cultural dimensions of globalization. Minneapolis: Univ. of Minnesota Press,

Aramberri, J. (2001) The Host Should Get Lost: Paradigms in the Tourism Theory. Annals of Tourism Research 28: 738-761.

Bauman Z. (2000) Liquid modernity. Cambridge: Polity.

Chang, T., Milne, S., Fallon D., Pohlmann, C. (1996) Urban Heritage Tourism: The Global-Local Nexus. Annals of Tourism Research 23: 284-305.

Eriksen Thomas Hylland (2001) Tyranny of the Moment: Fast and Slow Time in the Information Age. Pluto Press. ISBN: 9781783716234.

Featherstone, M. (1996) Localism, Globalism, and Cultural Identity. In R. Wilson, and W. Dissanayake, (eds.), Global/Local: Cultural Production and the Transnational Imaginary, pp. 46-77. Durham, NC: Duke University Press.

Featherstone, M., Lash, S., Robertson, R., (eds). (1995) Global Modernities. London: Sage.

Franklin, A. and Crang, M. (2001) The Trouble with Tourism and Travel Theory? Tourist Studies 1: 5-22.

Friedman, J. (1994) Cultural Identity and Global Process. London: Sage. 1994.

Giddens A. (2000) Runaway World: How Globalization is Reshaping Our Lives. New York.

Habermas J. (1992) Democracy. Consciousness. Moral. Moscow Lectures and interviews. (Transl) Moscow: Nauka,

Hannerz, U. (1996) Transnational Connections: Culture, People, Places. London: Routledge.

Nuryanti, W. (1996) Heritage and Postmodern Tourism. Annals of Tourism Research 23: 249-260.

Peter L. Berger and Samuel P. Huntington. Many Globalizations: Cultural Diversity in the Contemporary World. ISBN-13: 9780195151466. DOI:10.1093/0195151461.001.0001 Published to Oxford Scholarship Online: April 2004.

Robertson R. (1992) Globalization: Social Theory and Global Culture. Retrieved 20 February, 2020, from URL

https://books.google.ru/books?id=eVMmonrrZDkC\&lpg=PP5\&hl=ru\&pg=PP5\#v=onepage\&q\&f= false

Robertson, R. (1994) Globalization or Glocalization? Journal of International Communication 1: 33-52.

Robertson, R. (1995) Glocalization: Time-Space and Homogeneity-Heterogeneity. In Global Modernities. In Featherstone, M., Lash, S., and Robertson, R. (eds.), pp. 25-44. London: Sage.

Sherlock, K. Robertson, R. (2001) Revisiting the Concept of Hosts and Guests. Tourist Studies 1: 271-295.

Smith, V., Brent, M. (eds.) (2001) Hosts and Guests Revisited: Tourism Issues of the 21st Century. New York: Cognizant Communication Corporation.

Sztompka P. (2002) Socjologia Analiza Społeczeństwa Monography. ISBN: 978-83-240-0218-4 EAN: 9788324002184. Znak.

Teo, P., Li, L. (2003) Global and Local Interactions in Tourism. Annals of Tourism Research 30: 287-306.

Tulloch, S. (ed.) (1991) The Oxford Dictionary of New Words: A Popular Guide to Words in the News. Oxford: Oxford University Press. 